\title{
Phytochemical Investigation of Cassia spectablis Seeds Isolation and Structural Studies of Two New Flavone Glycosides
}

\author{
M. Singh and J. Singh* \\ Department of Chemistry, University of Allahabad, Allahabad, India \\ Z. Naturforsch. 40b, 550-552 (1985); received July 27, 1984 \\ Cassia Spectablis, Leguminosae, Flavone Glycosides \\ From the seeds of Cassia spectablis 6-hydroxy-4'-methoxy flavone-6-0-arabinopyranoside and \\ 3,5-dihydroxy-7,3', $4^{\prime}$-trimethoxy flavone-3-0-arabinopyranoside have been isolated and their \\ structure elucidated.
}

\section{Introduction}

Cassia spectablis is known for its medicinal properties and the plant is grown throughout India.

In previous paper [1] we have reported the occurrence of two esters and a chromone glycoside from Cassia spectablis seeds. In the present investigation of the same plant, we report the isolation and characterisation of two new flavone glycosides.

\section{Results and Discussion}

From the ethanolic extract of the seeds of Cassia spectablis two flavone glycosides $\mathrm{C}_{21} \mathrm{H}_{20} \mathrm{O}_{8}$ (1) m.p. $185^{\circ} \mathrm{C}$ (d) and $\mathrm{C}_{23} \mathrm{H}_{24} \mathrm{O}_{11}$ (2) m.p. $280{ }^{\circ} \mathrm{C}$ (d) have been isolated. Homogeneity and purity of these compounds were established by chromatography. $\mathrm{C}_{21} \mathrm{H}_{20} \mathrm{O}_{8}$ (1) was found to be a glycoside. On acid hydrolysis it gave arabinose and an aglycone $\mathrm{C}_{16} \mathrm{H}_{12} \mathrm{O}_{4}$, m.p. $245^{\circ} \mathrm{C}$ which showed colour reactions characteristic of flavone. The aglycone analysed for one hydroxyl group (mono acetate) and one methoxyl group (IR 2915 and $1185 \mathrm{~cm}^{-1}$ [2]; NMR $\delta$ $\left.3.75,3 \mathrm{H},-\mathrm{OCH}_{3}\right)$. UV spectral studies of the aglycone $\left(\lambda_{\max }^{\mathrm{EtOH}} 240,345 \mathrm{~nm}\right)$ indicated the absence of hydroxyl group at positions 5,7 and $4^{\prime}$ (No shift with $\mathrm{AlCl}_{3}, \mathrm{NaOAc}, \mathrm{NaOMe}$ ). The aglycone gave anisic acid on oxidation with neutral potassium permanganate, which confirmed the position of methoxyl group at position- 4 ' in ring B. NMR spectrum of the aglycone showed doublets at $\delta 7.28 \mathrm{ppm}\left(2 \mathrm{H}, \mathrm{H}-2^{\prime}\right.$, $\left.\mathrm{H}-6^{\prime}\right)$ and $7.00 \mathrm{ppm}\left(2 \mathrm{H}, \mathrm{H}-3^{\prime}, \mathrm{H}-5^{\prime}\right)$ representing $\mathrm{A}_{2} \mathrm{~B}_{2}$ system in ring C. NMR spectrum of the aglycone also showed signals of three protons for ring $\mathrm{A}$,

* Reprint requests to Dr. J. Singh.

Verlag der Zeitschrift für Naturforschung, D-7400 Tübingen 0340-5087/85/0400-0550/\$ 01.00/0 one at $\delta 6.60 \mathrm{ppm}(J=2.5 \mathrm{cps}, 9 \mathrm{cps}, 1 \mathrm{H}, \mathrm{H}-7)$; second at $\delta 6.88 \mathrm{ppm}(J=9 \mathrm{cps}, 1 \mathrm{H}, \mathrm{H}-8)$ and third at $\delta 7.60 \mathrm{ppm}(J=2.5 \mathrm{cps}, 1 \mathrm{H}, \mathrm{H}-5)$. The doublet at $\delta 7.60 \mathrm{ppm}$ was strongly deshielded by the 4 -keto group and was assigned to $\mathrm{H}-5$ proton [3].

The above results showed that the aglycone is 6-hydroxy-4'-methoxy flavone. The mass fragments at $m / z 136\left(\mathrm{~A}_{1}^{+}\right), m / z 132\left(\mathrm{~B}_{1}^{+}\right)$and $m / z 135\left(\mathrm{~B}_{2}{ }^{+}\right)$ also confirmed the proposed structure of the aglycone [4]. The aglycone is new and has not been isolated earlier from any plant source. Structure of the aglycone is finally confirmed by its synthesis: 2,5-dihydroxy acetophenone and anisaldehyde on condensation in alkaline medium gave 4-methoxy $2^{\prime}, 5^{\prime}$-dihydroxy chalcone m.p. $175^{\circ} \mathrm{C}$. The chalcone when treated with DDQ gave 6-hydroxy-4'-methoxy flavone [5]. This synthetic flavone was identified in every respect with the aglycone isolated from Cassia spectablis seeds.<smiles>COc1ccc(-c2cc(=O)c3cc(O)ccc3oc2=O)cc1</smiles>

The only position for attachment of arabinose to the aglycone is at C-6 hydroxyl. That arabinose in the glycoside is in the pyranose form has been proved by periodate oxidation when it consumed 2 moles of periodate per mole of the glycoside and produced one mole of formic acid. Thus the glycoside has been identified to be 6-hydroxy-4'-methoxy flavone-6-0arabinopyranoside (1). This glycoside is new and was not reported earlier. 


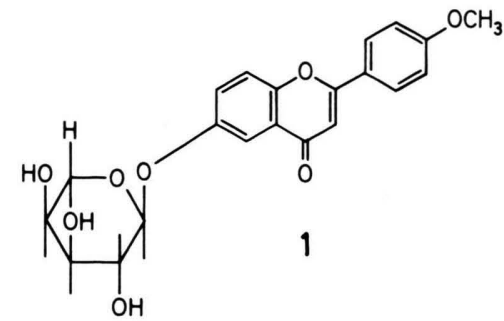

$\mathrm{C}_{23} \mathrm{H}_{24} \mathrm{O}_{11}$ (2) m.p. $280{ }^{\circ} \mathrm{C}$ (d) was also a glycoside and gave characteristic colour reactions of flavonol. On acid hydrolysis it gave arabinose and an aglycone $\mathrm{C}_{18} \mathrm{H}_{16} \mathrm{O}_{7}$, m.p. $205^{\circ} \mathrm{C}$. The aglycone gave characteristic colour reactions of flavonol and has been identified to be 3,5-dihydroxy-7,3',4'-trimethoxy flavone by standard colour reactions, spectral data (UV, IR, NMR and mass) and co-chromatography with an authentic sample.

Methylation of 2 followed by acid hydrolysis gave quercetin 5,7,3', $4^{\prime}$-tetra-0-methyl ether (m.p., m.m.p., co-chromatography) showing that sugar was linked at position-3 of the aglycone. That arabinose is present in the pyranose form has been proved by periodate oxidation. Thus the glycoside has been identified to be 3,5-dihydroxy-7,3',4'-trimethoxy flavone-3-0-arabinopyranoside (2). This glycoside is also new and was not reported earlier.

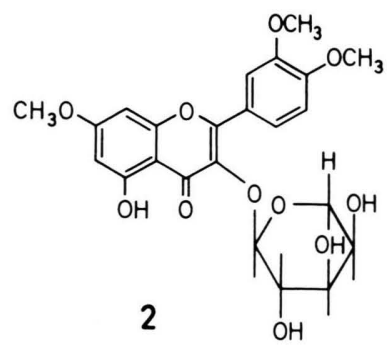

\section{Experimental}

The seeds were extracted with petrol ether. Petrol ether extract yielded two esters [1]. The defatted seeds were then extracted with EtOH and the conc. extract diluted with $\mathrm{H}_{2} \mathrm{O}$ to give coloured ppt and an aqueous solution.

The aqueous fraction was concentrated and successively extracted with ether and ethyl acetate. Extraction with $\mathrm{Et}_{2} \mathrm{O}$ and chromatography over silica gel with benzene-ethyl acetate $(1: 1)$ gave 1 m.p. $185^{\circ} \mathrm{C}(\mathrm{d})$. The ethyl acetate extract of the original aqueous solution gave two compounds (Sigel TLC; Benzene-Ethyl acetate, 1:9) which were separated by column chromatography. The benzene-ethylacetate $(4: 6)$ eluate contained a single entity on TLC, a chromone glycoside [1] whereas benzene-ethylacetate (1:9) eluate also contained single entity on TLC (Sigel, EtOAc), a yellow glycoside m.p. $280^{\circ} \mathrm{C}$ (d) (2).

$$
\begin{array}{ccc}
\mathrm{C}_{21} \mathrm{H}_{20} \mathrm{O}_{8}(\mathbf{1}), \text { m.p. } 185^{\circ} \mathrm{C}(\mathrm{d}) \\
\text { Calcd } & \mathrm{C} 63.00 & \mathrm{H} 5.00, \\
\text { Found } & \mathrm{C} 62.48 & \mathrm{H} 4.91 .
\end{array}
$$

$\mathrm{IR} v_{\max }^{\mathrm{KBr}} 3380,2915,2860,1700,1620,1530,1185$, $860,800,760$, and $690 \mathrm{~cm}^{-1}$.

$\mathrm{UV} \lambda_{\max }^{\mathrm{EtOH}} \mathrm{nm} 240,345 ; \mathrm{AlCl}_{3} 350, \mathrm{NaOAc} 240$, and $\mathrm{NaOMe} 365$.

Acid hydrolysis. $400 \mathrm{mg} 1$ were heated with $7 \%$ sulphuric acid for $4 \mathrm{~h}$ at $80^{\circ} \mathrm{C}$, diluted with water. The solution was extracted with $\mathrm{Et}_{2} \mathrm{O}$. The $\mathrm{Et}_{2} \mathrm{O}$ extract was evaporated to yield an aglycone crystallised from ethyl acetate - petroleum ether (3:1) m.p. $245^{\circ} \mathrm{C}$.

The aq layer was chromatographed on Whatman No. 1 paper in (a) EtOAc- $\mathrm{Py}-\mathrm{H}_{2} \mathrm{O}(12: 5: 4)$ and (b) EtOAc-iso $\mathrm{PrOH}-\mathrm{H}_{2} \mathrm{O}$ (3:1:1) using glucose, arabinose, xylose and mixtures of these as standard. The chromatogram was developped with (a) $p$ anisidine hydrochloride $(1 \mathrm{~g})$ and $\mathrm{NaHSO}_{3}(0.1 \mathrm{~g})$ in $\mathrm{MeOH}(10 \mathrm{ml})$ diluted to $100 \mathrm{ml}$ with $n-\mathrm{BuOH}$ and (b) aniline hydrogen phthalate spray at $120-130^{\circ} \mathrm{C}$ for 10-16 min.

$$
\begin{gathered}
\text { Aglycone }\left(\mathrm{C}_{16} \mathrm{H}_{12} \mathrm{O}_{4}\right) \\
\text { Calcd } \\
\text { m.p. } 245^{\circ} \mathrm{C} \\
\text { Found } 71.64 \text { C } 71.22 \text { H } 4.48, \\
\text { H } 4.52 .
\end{gathered}
$$

$\mathrm{IR} v_{\max }^{\mathrm{KBr}} 3380,2915,2865,1700,1625,1530,1185$, and $900 \mathrm{~cm}^{-1}$.

$\mathrm{UV} \lambda_{\max }^{\mathrm{EtOH}} \mathrm{nm} 240,345 ; \mathrm{AlCl}_{3} 245,350 ; \mathrm{NaOAc} 245$, 355; NaOMe 245, 370. NMR $\left(\mathrm{CdCl}_{3}, 100 \mathrm{MHz}\right) \delta$ : $3.75\left(\mathrm{~S}, 3 \mathrm{H},-\mathrm{OCH}_{3}\right) ; 6.34(\mathrm{~S}, 1 \mathrm{H}, \mathrm{H}-3) ; 6.60(\mathrm{dd}$, $J=2.5 \mathrm{cps}$, and $9 \mathrm{cps}, 1 \mathrm{H}, \mathrm{H}-7) ; 6.88(\mathrm{~d}, J=9 \mathrm{cps}$, $1 \mathrm{H}, \mathrm{H}-8) ; 7.60(\mathrm{~d}, J=2.5 \mathrm{cps}, 1 \mathrm{H}, \mathrm{H}-5) ; 7.28(\mathrm{~d}$, $\left.J=9 \mathrm{cps}, 2 \mathrm{H}, \mathrm{H}-2^{\prime}, \mathrm{H}-6^{\prime}\right)$, and 7.00 (d, $J=9 \mathrm{cps}$, $\left.2 \mathrm{H}, \mathrm{H}-3^{\prime}, \mathrm{H}-5^{\prime}\right)$.

Acetate $\left(\mathrm{Ac}_{2} \mathrm{O} / \mathrm{Py}\right)$ crystallised from ethyl acetate m.p. $207^{\circ} \mathrm{C}$. Methyl ether $\left(\left(\mathrm{CH}_{3}\right)_{2} \mathrm{SO}_{4} / \mathrm{K}_{2} \mathrm{CO}_{3}\right)$ crystallised from ethyl acetate: Pt ether m.p. $144^{\circ} \mathrm{C}$.

Synthesis: 2,5-dihydroxy acetophenone (2 g) and $4^{\prime}$-methoxy benzaldehyde $(1.85 \mathrm{~g})$ were dissolved in ethanol $(10 \mathrm{ml})$ and an aqueous solution of potassium hydroxide $(20 \%, 8 \mathrm{ml})$ added to the mixture kept at $0{ }^{\circ} \mathrm{C}$. After the usual work up the crude product crystallised from absolute alcohol, m.p. $175^{\circ} \mathrm{C}$. This chalcone $(200 \mathrm{mg})$ was refluxed with DDQ in dry benzene medium for $20 \mathrm{~h}$. After work up the reaction, the residue was purified using column 
chromatography when flavone crystallised as light yellow coloured needles (ethyl acetate - petroleum ether; m.p. $\left.245^{\circ} \mathrm{C}\right)$ yield, $100 \mathrm{mg}(\mathrm{C}=71.26 \% ; \mathrm{H}=$ $4.50 \%)$.

$\mathrm{C}_{23} \mathrm{H}_{24} \mathrm{O}_{11}$ (2): m.p. $280{ }^{\circ} \mathrm{C}$ (d) crystallised from ethyl acetate - Pt ether $(3: 1)$

Calcd C 57.98 H 5.04,

Found C 57.45 H 5.28.

$\mathrm{IR} v_{\max }^{\mathrm{KBr}}: 3350,2900,2850,1640,1500,1450,1185$, $1150,1130,835,810,760 \mathrm{~cm}^{-1}$.

$\mathrm{UV} \lambda_{\max }^{\mathrm{EtOH}} \quad \mathrm{nm}: \quad 255,370, \quad \mathrm{NaOAc} 255$; $\mathrm{H}_{3} \mathrm{BO}_{3}+\mathrm{NaOAc} 360 ; \mathrm{AlCl}_{3} 425 ; \mathrm{AlCl}_{3}+\mathrm{HCl} 410$; EtONa 415.

Acid hydrolysis: On acid hydrolysis $\left(7 \% \mathrm{H}_{2} \mathrm{SO}_{4}\right)$ it gave a yellow coloured aglycone and arabinose. The aglycone was crystallised from ethyl acetate - petroleum ether $(3: 1)$ m.p. $205^{\circ} \mathrm{C}[6]$.
Calcd
C 62.79
$\mathrm{H} 4.65$,
Found C 62,70 H 4.75.

Aglycone: $\mathrm{UV}_{2}^{\mathrm{EtOH}} \mathrm{nm}: 255,367 ; \mathrm{AlCl}_{3}$ 429; $\mathrm{AlCl}_{3}+\mathrm{HCl} 412 ; \mathrm{NaOEt} 417 ;$ NaOAc 255; $\mathrm{H}_{3} \mathrm{BO}_{3}+\mathrm{NaOAc} 410$.

IR $v_{\max }^{\mathrm{KBr}}: 3350,2900,2850,1640,1500,1450,1185$, $1150,1130,835,810 \mathrm{~cm}^{-1}$.

NMR $\left[\mathrm{CDCl}_{3}, 100 \mathrm{MHz}\right] \delta: 4.00\left(\mathrm{~S}, 9 \mathrm{H},-\mathrm{OCH}_{3}\right)$; $6.30(\mathrm{~d}, J=2.5 \mathrm{cps}, 1 \mathrm{H}, \mathrm{H}-6) ; 6.66(\mathrm{~d}, J=2.5 \mathrm{cps}$, $1 \mathrm{H}, \mathrm{H}-8) ; 7.80$ (dd, $J=2.5 \mathrm{cps}, 9 \mathrm{cps}, 2 \mathrm{H}, \mathrm{H}-2^{\prime}$, $\left.\mathrm{H}-6^{\prime}\right)$, and 6.90 (d, $\left.J=9 \mathrm{cps}, 1 \mathrm{H}, \mathrm{H}-5^{\prime}\right)$.

Mass (70 eV, direct inlet) $m / e$ 344, 329, 328, 314, 279, 270, 181, 175, 166, 162, 72.

Acetate $\left(\mathrm{Ac}_{2} \mathrm{O} / \mathrm{Py}\right)$ m.p. $180{ }^{\circ} \mathrm{C}$.

Methyl ether $\left(\left(\mathrm{CH}_{3}\right)_{2} \mathrm{SO}_{4} / \mathrm{K}_{2} \mathrm{CO}_{3}\right)$ m.p. $278{ }^{\circ} \mathrm{C}$.

One of us (M. Singh) is grateful to C.S.I.R. New Delhi, India for the award of Senior Research Fellowship.
[1] J. Singh and M. Singh, Z. Naturforsch. 39b, 1425 (1984).

[2] L. H. Briggs, L. D. Calebook, and W. Wildman, Anal. Chem. 29, 904 (1954).

[3] J. B. Harborne, T. J. Mabry, and H. Mabry, Chapman and Hall (London) first edition p. 64 (1975).
[4] Ibid, p. 82.

[5] K. Subrahmanyam, M. J. Rao, and J. K. V. Rao, Ind. J. Chem. 15B, 105 (1977).

[6] E. Wollenweber and K. Egger, Tetrahedron Lett. 1970, 1601. 